\title{
Selective cyclooxygenase-2 silencing mediated by engineered E. coli and RNA interference induces anti-tumour effects in human colon cancer cells
}

\section{A Strillacci', , C Griffoni', G Lazzarini ${ }^{1,2}$, MC Valerii ${ }^{1,2}$, S Di Molfetta', F Rizzello², M Campieri ${ }^{2}$, MP Moyer ${ }^{3}$, V Tomasi' and E Spisni*,i}

'Department of Experimental Biology, University of Bologna, via Selmi 3, Bologna 40126, Italy; ${ }^{2}$ Department of Clinical Medicine, St Orsola-Malpighi Hospital, via Massarenti 9, Bologna 40138, Italy; ${ }^{3}$ INCELL Corporation, Cimarron Path 12734, San Antonio, TX 78249, USA

BACKGROUND: Cyclooxygenase-2 (COX-2) overexpression is strongly associated with colorectal tumourigenesis. It has been demonstrated that the chronic use of non-steroidal anti-inflammatory drugs (COX inhibitors) partially protects patients from colorectal cancer (CRC) development and progression but induces severe cardiovascular side effects. New strategies for selective COX-2 blockade are required.

METHODS: We developed an improved technique, based on RNA interference (RNAi), to gain a selective COX-2 silencing in CRC cells by a tumour-dependent expression of anti-COX-2 short-hairpin RNA (shCOX-2). Anti-COX-2 shRNA-expressing vectors were delivered in CRC cells (in vitro) and in colon tissues (ex vivo) using engineered Escherichia coli strains, capable of invading tumour cells (InvColi).

RESULTS: A highly tumour-dependent shCOX-2 expression and a significant COX-2 silencing were observed in CRC cells following InvColi strain infection. Cyclooxygenase-2 silencing was associated with a strong reduction in both proliferative and invasive behaviour of tumour cells. We also demonstrated a pivotal role of COX-2 overexpression for the survival of CRC cells after bacterial infection. Moreover, COX-2 silencing was achieved ex vivo by infecting colon tissue samples with InvColi strains, leading to anti-inflammatory and anti-tumour effects.

CONCLUSION: Our RNAi/InvColi-mediated approach offers a promising tool for a highly selective COX-2 blockade in vitro and in vivo. British Journal of Cancer (2010) 103, 975-986. doi:I0.1038/sj.bjc.6605859 www.bjcancer.com

Published online 17 August 2010

(C) 2010 Cancer Research UK

Keywords: COX-2; CRC; RNAi; E. coli

Colorectal cancer (CRC) represents the third most common tumour in humans and the second leading cause of tumourrelated death in Western countries. In Europe, $>400000$ new cases and $>200000$ deaths per year are estimated (Ferlay et al, 2007). The mortality rate of CRC dramatically increases when tumour cells invade the primary tissue and generate lymph nodal and liver metastases. Owing to its high incidence and mortality rate, CRC is of great interest for the scientific community.

Over the last few decades, it has been demonstrated that the chronic use of non-steroidal anti-inflammatory drugs (NSAIDs), blocking isoforms 1 and 2 of the cyclooxygenase (COX) enzyme, confers a $40-50 \%$ reduction in the incidence of CRC (Phillips et al, 2002; Thun et al, 2002; Higuchi et al, 2003; Sandler et al, 2003). Cyclooxygenase is a key enzyme in the metabolism of arachidonate and regulates the synthesis of prostaglandins $(\mathrm{H} 2, \mathrm{D} 2, \mathrm{E} 2, \mathrm{~F} 2 \alpha, \mathrm{I} 2)$ and tromboxanes (TXA2 and TXB2), both having important roles as cellular mediators. Cyclooxygenase- 2 represents the product of the Cox-2 inducible gene. It is overexpressed in $40 \%$ of adenomas

*Correspondence: Dr A Strillacci; E-mail: antonio.strillacci@unibo.it and Dr E Spisni; E-mail: enzo.spisni@unibo.it

Received 16 April 2010; revised 21 July 20I0; accepted 22 July 2010; published online 17 August 2010 and in $80 \%$ of adenocarcinomas (Eberhart et al, 1994; Sano et al, 1995), and such an overexpression has been strongly associated with colon tumourigenesis both in vitro and in murine models (DuBois et al, 1996; Oshima et al, 1996; Williams et al, 1996). It is commonly accepted that COX-2 can contribute to CRC development and progression through mechanisms involving the stimulation of angiogenesis (Spisni and Tomasi, 1997; Iñiguez et al, 2003), the inhibition of apoptosis (Tsujii and DuBois, 1995) and the increase in cell migration/invasiveness (Yamauchi et al, 2002; Strillacci et al, 2006).

Celecoxib and rofecoxib were the first NSAIDs marketed as selective COX-2 inhibitors and they have been used in clinical trials to test their efficacy in the prevention and/or treatment of CRC. Unfortunately, celecoxib and, particularly, rofecoxib have been shown to significantly increase the risk of adverse cardiovascular events and myocardial infarction in treated patients (Bresalier et al, 2005; Solomon et al, 2005). Moreover, the cardiovascular toxicity of rofecoxib could be increased by its capability to directly inhibit prostacyclin synthase activity, as demonstrated by our group (Griffoni et al, 2007). Although celecoxib is still marketed, rofecoxib has been withdrawn from the worldwide market by Merck in September 2004.

RNA interference (RNAi) has rapidly become an innovative and elective tool for gene silencing at the post-transcriptional level. 
RNAi-mediated gene silencing can be achieved using small interfering RNA (siRNA) or short-hairpin RNA (shRNA) as precursor molecules. Although synthetic siRNAs are introduced in mammal cells using standard in vitro transfection methods, shRNAs are expressed after transfecting cells with plasmids (Lewis et al, 2002) or viral-based vectors (Brummelkamp et al, 2002). Numerous advantages come from shRNA-based RNAi approach: first, the possibility to obtain a long-term gene silencing; and second, the possibility to express shRNAs in a spatial- and/or temporal-specific manner using tissue-specific promoters or introducing regulatory elements on shRNA promoters.

In 2006, our research group demonstrated that it is possible to stably silence the COX-2 protein in a CRC cell line (HT-29) using the anti-COX-2 shRNA (shCOX-2). HT-29 $\mathrm{pS}^{\mathrm{S}(\operatorname{shCOX}-2)}$ showed a significant impairment of malignant behaviour (Strillacci et al, 2006) and a reduced ability to survive under hypoxic conditions (Sansone et al, 2009). To date, RNAi approaches have been used to efficiently silence the COX-2 protein in many different in vitro models (for a review, see Strillacci et al, 2010).

Several years ago, it was demonstrated that a functional gene transfer from bacteria to mammalian cells could occur. In particular, engineered Escherichia coli, expressing Inv and HlyA genes (from Yersinia pseudotuberculosis and Lysteria monocytogenes, respectively), was found to be able to invade and release DNA into host cells (Grillot-Courvalin et al, 1998). This phenomenon was also demonstrated in vivo, as it was observed that invasive E. coli can deliver therapeutic genes to the colonic mucosa in mice (Castagliuolo et al, 2005). Similarly, a successful transfer of shRNA into mammalian cells was achieved using nonpathogenic E. coli transformed with a plasmid containing expression cassettes for shRNA and Inv/HlyA genes. In 2006, Xiang et al (2006) applied this new strategy for the first time (termed 'trans-kingdom RNAi') to silence the $\beta$-1 catenin gene (CTNNB1) in human cells both in vitro and in vivo.

In this paper, we describe an effective method by which shCOX2-expressing vectors can be delivered into CRC cells (in vitro) and in COX-2-overexpressing colonic tissues (ex vivo), using invasive E. coli strains to achieve a strong COX-2 silencing mediated by RNAi, coupled to anti-tumour effects. This strategy may prove to be suitable for an in vivo application aiming at COX-2 inhibition and CRC prevention.

\section{MATERIALS AND METHODS}

\section{Cell lines}

Human cancer cell lines HCA-7, HT-29, HCT-116, HeLa and human transformed kidney cell line HEK-293 were obtained from the American Type Culture Collection (Manassas, VA, USA). Normal human colon mucosal epithelial cell line NCM-460 (Moyer et al, 1996) was obtained after a licensing agreement with INCELL Corporation (San Antonio, TX, USA). Both HT-29 ${ }^{\mathrm{pS}(-)}$ and HT$29^{\mathrm{pS}(\mathrm{shCOX}-2)}$ cells have been previously created by our group, as described elsewhere (Strillacci et al, 2006). Cell lines were cultured at $37^{\circ} \mathrm{C}$ in $5 \% \mathrm{CO}_{2}$ in Dulbecco's modified Eagle's medium (DMEM) supplemented with $10 \%$ heat-inactivated fetal calf serum (FCS), $2 \mathrm{mM}$ L-glutamine and kanamycin $100 \mu \mathrm{g} \mathrm{ml}^{-1}$. Both FCS and DMEM were purchased from Cambrex BioWhittaker (Charles City, IA, USA). The NCM-460 cells were cultured in the M3 base media obtained from INCELL Corporation. All other reagents were purchased from Sigma (St Louis, MO, USA).

\section{Colon tissue culture}

Fresh colon biopsies were collected from patients affected by acute ulcerative colitis during endoscopy and immediately cultured in the MegaCell RPMI-1640 medium (Sigma). Patients gave written informed consent to participate in the study, which was approved by the local ethical committee.

\section{Plasmids}

The empty pSUPER.retro vector $\left(\mathrm{pS}^{-}\right)$, based on the murine stem cell virus (MSCV) genome, was purchased from Oligoengine (Seattle, WA, USA). The pSUPER.retro vector expressing shCOX-2 under RNA pol III H1 promoter control $\left(\mathrm{pS}^{\mathrm{H1}}\right)$ was created as described elsewhere (Strillacci et al, 2006). pSUPER.retro vectors expressing shCOX-2 under control of human Cox-2 promoter $\left(\mathrm{pS}^{\mathrm{COX}-2}\right)$ and TBE (Tcf-binding element)-based promoter $\left(\mathrm{pS}^{\mathrm{TBE}}\right)$ were created as follows: in both vectors, RNA pol III transcription stop signal was substituted with a SV40 polyA sequence between HindIII and SalI restriction sites (SV40 polyA sequence was amplified from the hER/pSG5 expression plasmid; forward primer: 5'-CCCAAGCTTAAATAAAGCAATAGCATCAC-3'; reverse primer: $5^{\prime}$-TAGAGTCGACCAGACATGATAAGAT-3', $120 \mathrm{bp}$ product); in $\mathrm{pS}^{\mathrm{COX}-2}$, the $\mathrm{H} 1$ promoter ( $\left.\mathrm{pH} 1\right)$ was substituted with the human Cox-2 promoter sequence (pCOX-2) between ApaI and BglII restriction sites (pCOX-2 sequence was amplified from HCA-7 genomic DNA; forward primer: 5'-CGGGCCCTGAGCACTACCC ATGATA- ${ }^{\prime}$; reverse primer: 5'-GAAGATCTCCGAGAGAA CCTTCC-3', 1254 bp product); in $\mathrm{pS}^{\mathrm{TBE}}, \mathrm{pH} 1$ was substituted with the TBE-based promoter sequence (pTBE) between ApaI and BglII restriction sites (the pTBE sequence was amplified from TOPFLASH plasmid, kindly provided by Dr Hans Clevers, University Hospital, Utrecht, The Netherlands; forward primer: $5^{\prime}-\mathrm{CG}$ GGCCCAAGCTATCAAAGGG-3'; reverse primer: 5'-CGAGAT CTGGCGCCTCAGCTGGC-3', $151 \mathrm{bp}$ product). A comprehensive scheme of $\mathrm{pS}$ vectors described above is shown in Figure 1.

\section{Transfections}

HCA-7, HT-29, HCT-116, NCM-460, HeLa and HEK-293 cells were seeded in 6 -well plates $\left(\sim 7 \times 10^{5}\right.$ cells per well $)$ at $70 \%$ confluence. After $24 \mathrm{~h}$, cells were transfected with $\mathrm{pS}^{-}, \mathrm{pS}^{\mathrm{H1}}, \mathrm{pS}^{\mathrm{COX}-2}$ and $\mathrm{pS}^{\mathrm{TBE}}$ vectors using Lipofectamine 2000 transfection reagent (Invitrogen, Carlsbad, CA, USA) according to the manufacturer's instructions. After $6 \mathrm{~h}$ of incubation at $37^{\circ} \mathrm{C}$, the transfection medium was replaced with $2 \mathrm{ml}$ of complete medium containing $10 \%$ FCS. Cells were lysed $48 \mathrm{~h}$ after transfection for real-time PCR and western blot analyses.

\section{RNA extraction and real-time PCR}

Total RNA from cultured cells was extracted using Eurozol reagent (Celbio, Milan, Italy) according to the manufacturer's instructions. Extracted RNA samples were treated with DNase I to remove any genomic DNA contamination using DNA-free kit (Ambion, Austin, TX, USA) and reverse transcribed using RevertAid First-Strand cDNA Synthesis Kit (Fermentas, Burlington, Ontario, Canada). Both COX-2 and $\beta$-glucuronidase (GUSB) mRNAs were reverse transcribed using random hexamer primers (Fermentas). The siCOX-2 was reverse transcribed using the stem-loop RT-PCR technique (Chen et al, 2005) using the following primer: $5^{\prime}-\mathrm{G}$ TCGTATCCAGTGCAGGGTCCGAGGTATTCGCACTGGATACGAC AAATTCC- $3^{\prime}$. U6 RNA was reverse transcribed using the following primer: $5^{\prime}$-AAAATATGGAACGCTTCACG- $3^{\prime}$. Both COX-2 mRNA and siCOX-2 levels were analysed by real-time PCR using SYBR supermix (Bio-Rad, Hercules, CA, USA) and iCycler system (BioRad) according to the manufacturer's instructions. The melting curve data were collected to check PCR specificity. Each cDNA sample was analysed in triplicate. Cyclooxygenase- 2 mRNA levels were normalised against GUSB mRNA, whereas siCOX-2 expression was normalised against U6 RNA levels. Relative expressions were calculated using the formula $2^{-2 \Delta \mathrm{Ct}}$ values $(\Delta \mathrm{Ct}=$ $\left.\mathrm{Ct}_{\text {gene }}-\mathrm{Ct}_{\mathrm{hk}}\right)$. Cyclooxygenase-2 primer pair: $5^{\prime}$-CCTGTGCCTGAT 

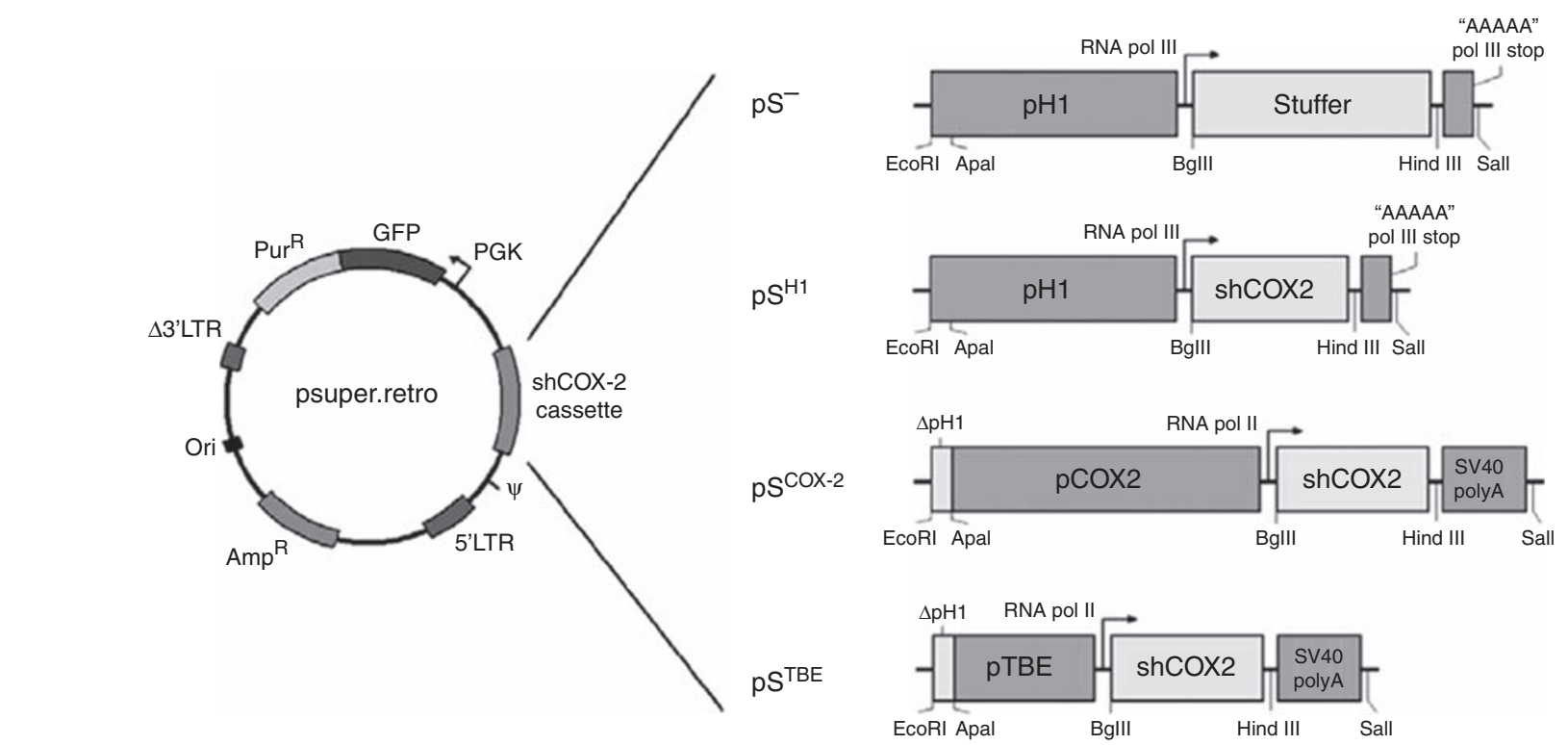

Figure I Scheme of pSUPER.retro vectors. $\mathrm{pS}^{-}$: original empty pSUPER.retro vector, with $\mathrm{HI}$ promoter upstream 'stuffer' sequence; $\mathrm{pS}^{\mathrm{HI}}$ : $\mathrm{pSUPER}$.retro vector in which shCOX-2 expression is controlled by $\mathrm{HI}$ promoter; $\mathrm{pS}^{\mathrm{COX}-2}$ : pSUPER.retro vector in which shCOX-2 expression is controlled by human Cox-2 promoter; $S^{T B E}$ : pSUPER.retro vector in which shCOX-2 expression is controlled by a TBE-based promoter (carrying Tcf-binding elements).

GATTGC- $3^{\prime}$ and $5^{\prime}$-CTGATGCGTGAAGTGCTG-3' $(165 \mathrm{bp}$ product); siCOX-2 primer pair: $5^{\prime}$-GCAACTGCTCAACACCG- $3^{\prime}$ and $5^{\prime}$-TGCAGGGTCCGAGGTAT-3' (56 bp product); GUSB primer pair: $5^{\prime}$-TGGTATAAGAAGTATCAGAAGCC-3' and $5^{\prime}$-GTATC TCTCTCGCAAAAGGAAC-3' (297 bp product); U6 primer pair: $5^{\prime}$-CTTCGGCAGCACATATACT-3' and 5'-AAAATATGGAACG CTTCACG-3' (99 bp product).

\section{InvColi strains and bacterial infection}

The E. coli (DH5 $\alpha$ strain) was co-transformed with the pGB2- $\Omega$ inv-hly plasmid $\left(\mathrm{Sm}^{R+}\right.$, kindly provided by Dr Catherine GrillotCourvalin, Institut Pasteur, Paris) and pSUPER.retro $\left(A m p^{R+}\right)$ vectors to obtain $E$. coli invasive strains carrying the three different shCOX-2 expression vectors (namely InvColi-pS ${ }^{\mathrm{H} 1}$, InvColi$\mathrm{pS}^{\mathrm{COX}-2}$ and InvColi-pS ${ }^{\mathrm{TBE}}$ ) and the negative control (InvColi$\mathrm{pS}^{-}$). Selection of co-transformed strains was based on both streptomycin and ampicillin resistance. Both HT-29 and HCA-7 cell lines were infected with InvColi strains according to the following procedure: cells were seeded in $25 \mathrm{~cm}^{2}$ flasks at $50 \%$ confluence $\left(\sim 3 \times 10^{6}\right.$ cells) in an antibiotic-free medium (DMEM); InvColi strains were grown in $\mathrm{LB}$ medium at $37^{\circ} \mathrm{C}$ to reach an $\mathrm{OD}_{600}$ of $\sim 1.00$; InvColi bacteria were then washed twice in fresh LB medium, re-suspended in antibiotic-free DMEM and added to cells' media at an MOI (multiplicity of infection) of 1:1000; after $2 \mathrm{~h}$ of incubation at $37^{\circ} \mathrm{C}$ in $5 \% \mathrm{CO}_{2}$, cells were washed and fresh DMEM medium supplemented with kanamycin was added to the flasks. Cells were lysed $48 \mathrm{~h}$ after infection for western blot and real-time PCR analyses. With regard to colon tissue samples, infection was achieved immediately after endoscopic resection by co-culturing biopsies and InvColi-pS strains in MegaCell RPMI1640 medium as described above. Biopsies were lysed and supernatants were collected $48 \mathrm{~h}$ after infection for western blot, real-time PCR and Luminex (Luminex, Austin, TX, USA) analyses.

\section{Western blot}

Cultured cells were homogenised in lysis buffer $(50 \mathrm{~mm}$ Tris- $\mathrm{HCl}$, $\mathrm{pH} 7.5,2 \mathrm{~mm}$ EDTA, $100 \mathrm{~mm} \mathrm{NaCl}, 1 \%$ Triton X-100, protease inhibitors mixture). Cell lysates were incubated $1 \mathrm{~h}$ on ice and centrifuged at $12000 \mathrm{~g}$ to collect supernatants. After addition of
SDS - PAGE sample buffer and boiling, $40 \mu \mathrm{g}$ of denatured proteins was separated in $12 \%$ SDS-PAGE and then transferred onto nitrocellulose papers. After blotting, nitrocellulose papers were incubated with specific antibodies. The primary antibodies used were polyclonal anti-COX-2 (Cayman Chemicals, Ann Arbor, MI, USA) and anti- $\beta$-actin (Sigma). Secondary antibodies (HRP conjugated) were purchased from Santa Cruz Biotechnology (Santa Cruz, CA, USA). Immunolabelling was visualised using the ECL procedure (Amersham Biosciences, Piscataway, NJ, USA). Bands were quantified using densitometric image analysis software (Quantity One, Bio-Rad). Normalisation was made against $\beta$-actin expression.

\section{Fluorescence and Inv-HlyA-pTBE sequence detection}

InvColi $\mathrm{pS}^{\mathrm{TBE}}$-infected cells were analysed $48 \mathrm{~h}$ after infection using the Nikon Eclipse $90 \mathrm{i}$ microscope (Nikon, Tokyo, Japan) to detect green fluorescent protein (GFP) expression. The total DNA of infected cells was extracted using phenol/chloroform procedure $24 \mathrm{~h}$ after infection, and the presence of pGB2- $\Omega$-inv-hly and $\mathrm{pS}^{\mathrm{TBE}}$ plasmids was confirmed by standard PCR technique, followed by agarose gel electrophoresis analysis. Inv primer pair: $5^{\prime}$-GCCAA TAAGGAGCAGGAGAC- $3^{\prime}$ and $5^{\prime}$-CCAAGGAGCCAGCCAATC- $3^{\prime}$ (225 bp product); HlyA primer pair: 5'-CATTTCACATCGTC CATCTATTTG- $3^{\prime}$ and $5^{\prime}$-TTACCGTTCTCCACCATTCC-3' (100 bp product); pTBE sequence primer pair (see above). The PCR analysis was also performed on E. coli co-transformed with pGB2$\Omega$-inv-hly and $\mathrm{pS}^{\mathrm{TBE}}$ plasmids (pre-heated at $95^{\circ} \mathrm{C}$ for $5 \mathrm{~min}$ ) and on purified plasmids themselves.

\section{Cell proliferation and viability analysis}

Both HT-29 and HCA-7 cells were infected with InvColi strains. Twenty-four hours after infection (day 0), cells were seeded in 12-well plates (HT-29: $5 \times 10^{4}$ cells per well; HCA-7: $2 \times 10^{4}$ cells per well). On days $1,2,3,6$ and 8 , cells were trypsinised, resuspended in PBS $1 \times$ and incubated for $10 \mathrm{~min}$ in $0.4 \%$ Trypan Blue (Sigma). Cells were then counted in a haemocytometer for unstained (viable) and stained cells. The percentage of cell viability was calculated as ((number of unstained cells)/(number of total cells)) $\times 100$. 


\section{Cell invasion assay}

Invasion assay was performed using Boyden chambers (New Technologies Group, Milan, Italy) with $8-\mu \mathrm{m}$ pore polycarbonate membranes (New Technologies Group). Membranes were coated with Matrigel (Sigma) at 40-fold dilution. Assay was performed using fresh DMEM supplemented with $10 \%$ heat-inactivated FCS as the chemoattractant agent. Forty-eight hours after InvColi infection, viable HT-29 and HCA-7 cells were added into the upper chamber at high density $\left(3 \times 10^{5}\right.$ cells $)$ either in the absence or presence of phorbol 12-myristate 13-acetate (PMA) $40 \mathrm{~nm}$ stimulation and then incubated for $24 \mathrm{~h}$ at $37^{\circ} \mathrm{C}$. After incubation, membranes were disassembled and non-invasive cells on the upper surface of the membrane were wiped with a cotton swab. The invasion index was determined by counting under light microscopy the number per optical fields ( $\times 200$ magnification $)$ of cells that migrated to the lower side of each membrane, after fixing and staining membranes with $2 \%$ Toluidine Blue.

\section{Cytokines, chemokines, growth factors and $\mathrm{PGE}_{2}$ detection}

Simultaneous detection of 29 extracellular factors released by treated colon tissue samples was performed using Luminex technology based on multiplexed bead immunoassay. Before assay, cell media samples were concentrated 10 times using Microcon spin devices (YM3, Millipore, Billerica, MA, USA) and subsequently re-suspended in Bio-Plex (Bio-Rad) assay buffer. The levels of 27 cytokines, chemokines and growth factors (IL-1 $\beta$, IL-1ra, IL-2, IL-4, IL-5, IL-6, IL-7, IL-8, IL-9, IL-10, IL-12(p70), IL-13, IL-15, IL-17, PDGF-bb, bFGF, G-CSF, GM-CSF, VEGF, TNF $\alpha$, IFN $\gamma$, IP-10, Eotaxin, MCP-1, MIP- $1 \alpha$, MIP-1 $\beta$, Rantes) were measured using the human ultrasensitive cytokine 27-plex antibody bead kit (Bio-Rad). The IL-1 $\alpha$ level was measured using Milliplex Map kit (Millipore), whereas $\mathrm{PGE}_{2}$ levels were measured using the Luminex Prostaglandin $\mathrm{E}_{2}$ Kit (Cayman Chemicals). The assays were performed in 96-well filter plates, as per the manufacturers' instructions. Concentration values were estimated using a standard curve and a fifth-order polynomial equation and were expressed as $\mathrm{ng} \mathrm{ml}^{-1}$ or $\log \left(\mathrm{pg} \mathrm{ml}^{-1}\right)$, after adjusting for the dilution factor (Bio-Plex Manager software 5.0, Bio-Plex). The intra-assay CV, including ultrafiltration and immunoassay, averaged $20 \%$.

\section{Statistical analysis}

Data were expressed as mean \pm s.e.m. of three independent experiments. Analysis of variance was used to assess the statistical significance of the differences. Differences were considered statistically significant at $P<0.01$.

\section{RESULTS}

\section{Selective expression of siCOX-2 in colon cancer cells}

In 2006, our group demonstrated that the COX-2 protein can be efficiently and stably downregulated by a constitutive expression of siRNA targeting COX-2 mRNA (siCOX-2) (Strillacci et al, 2006). The HT-29 colon cancer cell line was transduced with a retroviral vector (pSUPER.retro) containing an expressing cassette for shCOX-2 (siCOX-2 precursor molecule). In the pSUPER. retro vector, the transcription of shRNA sequence is driven by the human $\mathrm{H} 1$ promoter for RNA pol III $\left(\mathrm{pS}^{\mathrm{Hl}}\right)$. H1-driven transcription leads to a constitutive expression of shRNA molecules in almost every different type of transduced human cells. To improve the selectivity of siCOX-2 expression, we modified the expression cassette of shCOX-2 by substituting the promoter element. In particular, we created the $\mathrm{pS}^{\mathrm{COX}-2}$ vector, in which the $\mathrm{H} 1$ promoter ( $\mathrm{pH} 1)$ was substituted with the human Cox-2 promoter (pCOX-2), and the $\mathrm{pS}^{\mathrm{TBE}}$ vector, in which $\mathrm{pH} 1$ was substituted with a promoter containing TBEs (pTBEs), derived from TOPFLASH plasmid (largely used for luciferase assays). In both cases, shCOX2 transcription is driven by RNA pol II that needs a polyA stop signal (which has been introduced in pS-modified vectors, downstream of shCOX-2 sequence) (Figure 1). Using this approach, we made shCOX-2 expression dependent on COX-2 and on $\mathrm{Wnt} / \beta$-catenin cellular pathways, both highly activated in CRC cells. In fact, it is well known that CRC cells overexpress the COX-2 protein and this phenomenon depends on transcriptional (Yamamoto et al, 1995; Duque et al, 2005; Wu et al, 2005; Kaidi et al, 2006) and post-transcriptional regulation (Dixon et al, 2001; Strillacci et al, 2009). On the other hand, $\beta$-catenin is preferentially localised at the plasma membrane of normal colonocytes and promotes cellular adhesion, linking E-cadherin to the cytoskeleton. In CRC cells, as a consequence of mutations (Morin et al, 1997) and/or other cellular stimuli (Brabletz et al, 2001; Castellone et al, 2005), $\beta$-catenin frequently translocates in the nucleus and promotes the transcription of genes involved in cell proliferation, migration, survival, angiogenesis and stemness (Brabletz et al, $2005)$. In the nucleus, $\beta$-catenin associates with the transcriptional complex Tcf-4/Lef-1 (T-cell factor 4/lymphoid enhancer factor 1) and binds DNA on TBE promoter sequences. Figure 2 shows the expression levels of siCOX-2 in different human cell lines transiently transfected with $\mathrm{pS}^{-}$(empty vector, negative control), $\mathrm{pS}^{\mathrm{H1}}, \mathrm{pS}^{\mathrm{COX}-2}$ and $\mathrm{pS}^{\mathrm{TBE}}$ vectors. By transfecting CRC cell lines with $\mathrm{pS}^{\mathrm{COX}-2}$ and $\mathrm{pS}^{\mathrm{TBE}}$ vectors, it is possible to gain a highly selective expression of siCOX-2. In fact, in HT-29 and HCA-7 colon cancer cells, siCOX-2 expression driven by pCOX-2 and pTBE promoters resulted to be even higher than siCOX-2

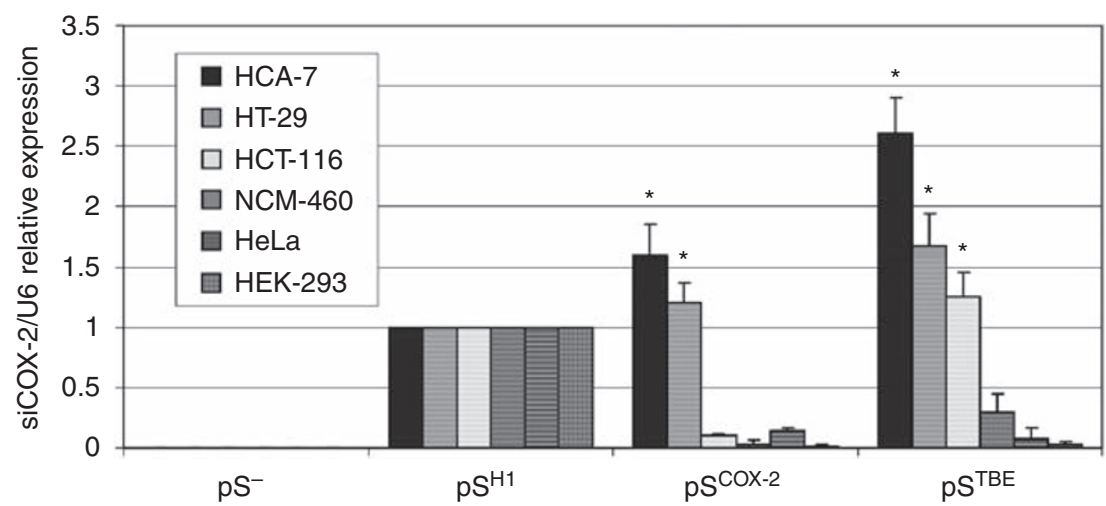

Figure 2 Selective expression of siCOX-2 in CRC cells. Six human cell lines were transfected with pS vectors, and siCOX-2 expression was evaluated by real-time PCR ( $48 \mathrm{~h}$ after transfection) and normalised against U6 RNA expression. For each cell line, relative expression of siCOX-2 refers to $\mathrm{pS}^{\mathrm{HI}}$-transfected sample. Data represent mean \pm s.e.m. of three independent experiments. $* \mathrm{P}<0.0 \mathrm{I}$. 
expression driven by the $\mathrm{pH} 1$ promoter. As expected, in the HCT116 colon cancer cell line (that does not express the COX-2 protein), we did not record a significant expression of siCOX-2 driven by pCOX-2, whereas siCOX-2 expression driven by $\mathrm{pTBE}$ was slightly higher than $\mathrm{pH} 1$. On the contrary, in NCM-460 (normal epithelial colon cells), HeLa (human cervix carcinoma cells) and HEK-293 (human transformed kidney cell line) cells, siCOX-2 expression driven by pCOX-2 and pTBE resulted to be very low, if compared with $\mathrm{pH} 1$-driven siCOX-2 expression.

\section{InvColi infection induces COX-2 silencing in CRC cell lines and significantly reduces $\mathrm{PGE}_{2}$ synthesis and release}

In 1998, Grillot-Courvalin et al (1998) showed that an engineered E. coli strain, expressing heterologous Inv and HlyA genes, was able to infect/invade mammalian cells and release DNA into host cells. On the basis of this approach, we developed a strategy to induce an RNAi-mediated COX-2 silencing in HT-29 and HCA-7 colon cancer cell lines. Bacterial LPS is known to induce COX-2 expression in human cells (Hla and Neilson, 1992). Thus, we first tested bacterial infection on CRC cells using InvColi-pS ${ }^{-}$(see the 'Materials and Methods' section for details on InvColi-pS strains) at different MOIs. At an MOI value of 1:1000, we did not record any significant COX-2 overexpression due to the presence of bacterial LPS (data not shown). Second, we provided evidence that InvColi strains created in our laboratory were able to infect and invade human CRC cells at an MOI of 1:1000. To this purpose, we used the InvColi-pS ${ }^{\mathrm{TBE}}$. $\mathrm{pS}^{\mathrm{TBE}}$ vector, as the other $\mathrm{pS}$ vectors described above, carries a GFP reporter gene. Both HT-29 and HCA-7 cells infected with InvColi-pS ${ }^{\text {TBE }}$ started to express the GFP protein $48 \mathrm{~h}$ after infection (Figure $3 \mathrm{~A}$ and $\mathrm{B}$ ). An $\sim 90 \%$ infection/ invasion efficiency was estimated on both cell lines. Moreover, soon after infection, it was possible to detect inside the cells, by PCR analysis, the presence of Inv-HlyA and pTBE sequences, carried by the pGB2- $\Omega$-inv-hly plasmid and $\mathrm{pS}^{\mathrm{TBE}}$ vector, respectively (Figure $3 \mathrm{C}$ ).

Using the InvColi-mediated RNAi approach, we achieved a high COX-2 silencing in CRC cell lines. In fact, $48 \mathrm{~h}$ after infection with invasive InvColi strains transformed with shCOX-2-expressing vectors (InvColi-pS ${ }^{\mathrm{H} 1}$, InvColi-pS ${ }^{\mathrm{COX}-2}$ and InvColi-pS ${ }^{\mathrm{TBE}}$ ), we started to observe a significant reduction in COX-2 protein and mRNA levels in HT-29 and HCA-7 cells (Figure 3D and E). Interestingly, COX-2 silencing with InvColi-pS $S^{\mathrm{TBE}}$ was more effective than the silencing obtained with InvColi-pS ${ }^{-}$(negative control) or InvColi-pS ${ }^{\mathrm{H1} / \mathrm{COX}-2}$ bacteria. Most likely, the stronger COX-2 silencing obtained with InvColi-pS ${ }^{\mathrm{TBE}}$ was dependent on a higher siCOX-2 expression, as detected in both HT-29 and HCA-7 cells (Figure 3D and E). Silencing results were highly comparable with those obtained after transfection of pS vectors into HT-29 and HCA-7 cells using the Lipofectamine 2000 Transfection Reagent (Invitrogen) (see Supplementary Material). We recorded a significant COX-2 protein silencing up to 5 days after InvColi-pS infection (data not shown). Very interestingly, prolonged COX-2 inhibition was associated with a strong impairment of $\mathrm{PGE}_{2}$ production (Figure 4) and, as previously
A



HT-29

D HT-29

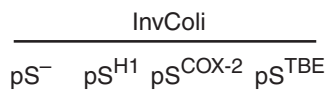

COX-2 $72 \mathrm{kDa}$

$\beta$-actin $42 \mathrm{kDa}$

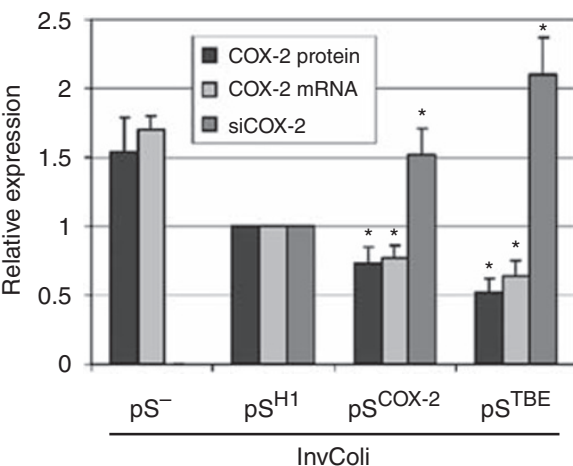

B

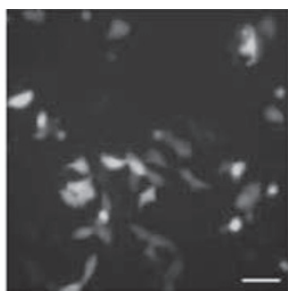

HCA-7

C

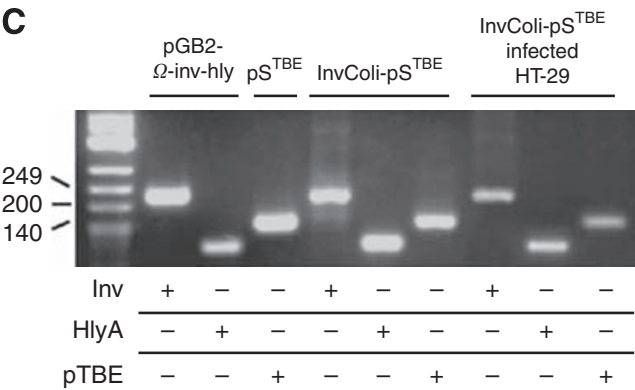

E

E $\mathrm{HCA}-7$

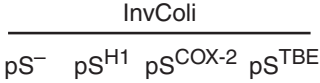

COX-2 $72 \mathrm{kDa}$

$\beta$-actin 42 kD



Figure 3 InvColi-pS strains infect CRC cells and induce high COX-2 silencing. GFP protein expression was evaluated in (A) HT-29 and in (B) HCA-7, $48 \mathrm{~h}$ after InvColi- pS ${ }^{\mathrm{TBE}}$ infection (bar $\left.=30 \mu \mathrm{m}\right)$. (C) PCR analysis of Inv, HlyA and pTBE loci was performed on pGB2- $\Omega$-inv-hly- and pS ${ }^{T B E}$-purified plasmids, on lysed InvColi-pS ${ }^{T B E}$ bacteria and on InvColi-pS ${ }^{T B E}$-infected HT-29 cells. PCR products were analysed after electrophoresis on $2 \%$ agarose gel. COX-2 protein, COX-2 mRNA and siCOX-2 levels were detected in (D) HT-29 and (E) HCA-7 cells, 48 h after InvColi strain infection, by western blot and real-time PCR. COX-2 protein, COX-2 mRNA and siCOX-2 expression was normalised against $\beta$-actin protein, GUSB ( $\beta$-glucuronidase) mRNA and U6 RNA levels, respectively. Relative expression of COX-2 protein, COX-2 mRNA and siCOX-2 refers to InvColi-pS ${ }^{\mathrm{HI}}$-infected sample. Data represent mean \pm s.e.m. of three independent experiments. $* P<0.01$. 
demonstrated with western blot analysis, the strongest inhibitory effect was obtained after InvColi-pS ${ }^{\mathrm{TBE}}$ infection.

We also evaluated whether COX-2 silencing induced by InvColiRNAi might have been the result of an off-target effect depending on interferon system activation (in particular, the Jak-STAT

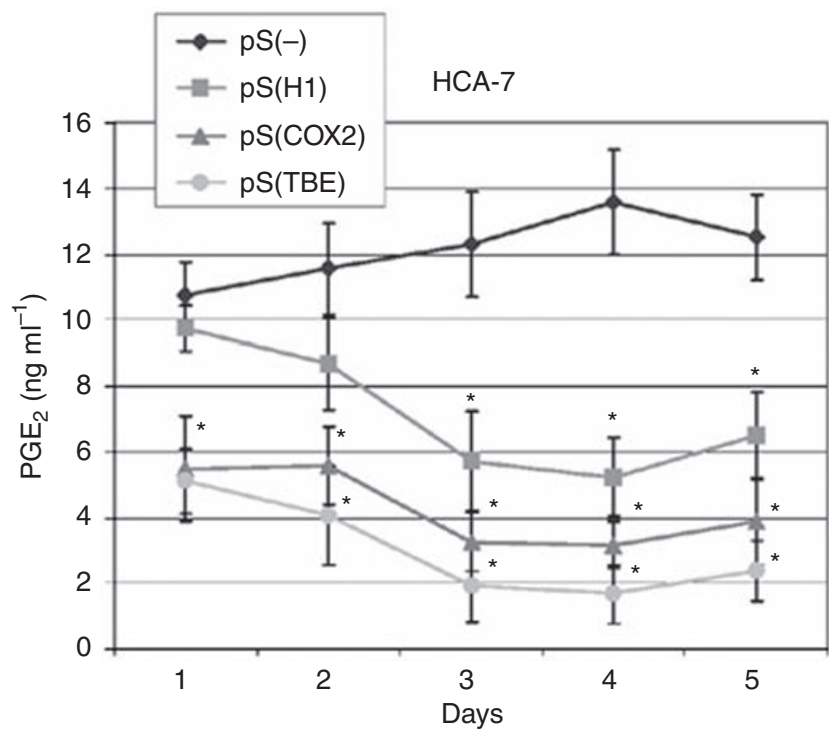

Figure 4 Effect of COX-2 silencing mediated by InvColi-pS on $\mathrm{PGE}_{2}$ production and release. Levels of $\mathrm{PGE}_{2}$ were quantified in conditioned media derived from InvColi-pS-infected HCA-7 cells, up to 5 days after

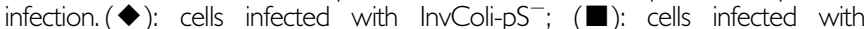
InvColi-pS ${ }^{H I} ;(\boldsymbol{\Lambda})$ : cells infected with InvColi-pS ${ }^{\mathrm{CO} X}-2 ;(\mathbf{O})$ : cells infected with InvColi-pS ${ }^{\mathrm{TBE}}$. Analysis was carried out by a Luminex-based multiplexed bead immunoassay. Concentration values are expressed as $\mathrm{ng} \mathrm{ml}^{-1}$ and represent mean $\pm \mathrm{CV}$ of three independent measurements, normalised considering the total protein amount extracted from each tissue sample. $* P<0.01$. pathway) (Sledz et al, 2003). Western blot analysis of phosphoSTAT-1(Tyr701) (active form) levels, normalised against p85/p91 STAT-1 total protein levels, showed that the interferon system response was triggered only at high MOI values (1:100), whereas infection at MOI 1:1000 did not have any effect on STAT-1 phosphorylation (data not shown).

\section{COX-2 silencing mediated by RNAi after InvColi infection impairs proliferation, survival and invasiveness of CRC cells}

As we have demonstrated an effective COX-2 silencing in CRC cells mediated by InvColi-pS strains, we have further investigated the phenotype of infected cells. Figure 5 shows data regarding proliferation and viability of COX-2-silenced HT-29 (Figure 5A and B) and HCA-7 (Figure 5C and D) cells and results were in high accordance in both cell lines. InvColi-pS ${ }^{\mathrm{COX}-2}$ and, in particular, InvColi-pS ${ }^{\mathrm{TBE}}$ infection induced a significant reduction in CRC cell proliferation and viability, despite InvColi- $\mathrm{pS}^{\mathrm{H} 1}$ infection that led only to a slight reduction. As COX-2 overexpression is involved in the malignant behaviour and invasiveness of CRC cells, we analysed the effect of the specific COX-2 silencing mediated by InvColi-RNAi in HT-29 and HCA-7 cells by performing a cell invasion assay, $48 \mathrm{~h}$ after InvColi infection. The invasion index of both cell lines was significantly reduced after COX-2 silencing (Figure 6A and B). Although in HT-29 we did not record any significant difference between the effectiveness of InvColi-pS $S^{\mathrm{H} 1}$, InvColi-pS $\mathrm{COX}^{\mathrm{CO}}$ and InvColi-pS ${ }^{\mathrm{TBE}}$, in HCA-7 InvColi-pS ${ }^{\mathrm{COX}-2}$ and InvColi-pS ${ }^{\mathrm{TBE}}$, infection induced a stronger reduction in the invasion index with respect to InvColi-pS ${ }^{\mathrm{H} 1}$. The impairment of the invasive behaviour of CRC cells due to RNAimediated COX-2 silencing was further confirmed after stimulation with PMA, which is known to induce COX-2 expression (Crofford et al, 1994) and promote cancer cell invasion (Han et al, 2000) (Figure 6A and $\mathrm{B}$ ). These findings are in line with our previous work in which we demonstrated that a stable COX-2 downregulation in HT-29 cells, mediated by pH1-driven shCOX-2
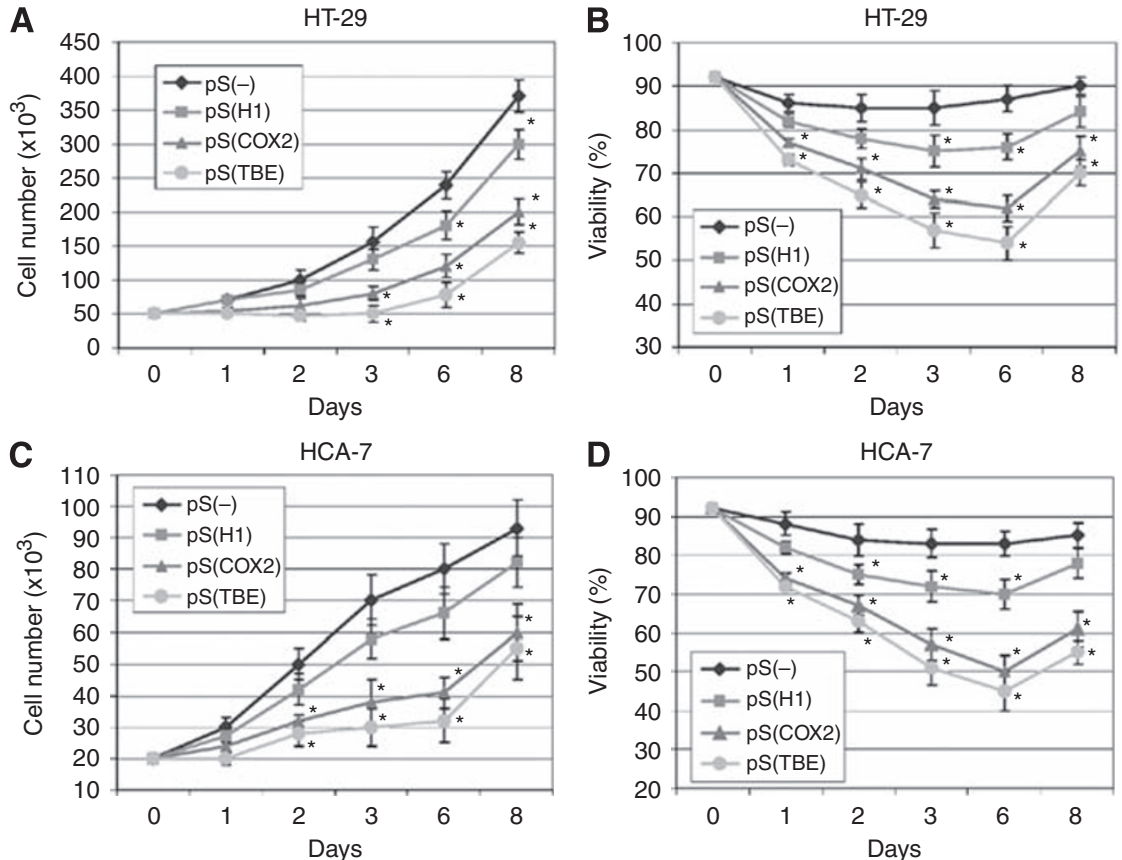

Figure 5 Effect of COX-2 silencing mediated by InvColi-pS on CRC cell proliferation and viability. Cell number and cell viability were evaluated in (A. B infected HT-29 and (C, D) HCA-7 cells, respectively. $\left(\begin{array}{c}\bullet \\ \text { : cells infected with InvColi-pS }\end{array}\right.$ InvColi-pS ${ }^{\mathrm{COX}-2} ;(\mathbf{O})$ : cells infected with InvColi-pS ${ }^{\mathrm{TBE}}$. Viability was evaluated using the Trypan Blue exclusion assay and quantified as ((number of unstained cells)/(number of total cells) $) \times 100$. Data represent mean \pm s.e.m. of three independent experiments. $* P<0.01$. 
A



B



Figure 6 Effect of COX-2 silencing mediated by InvColi-pS on CRC cell invasiveness. Invasion index was evaluated in (A) HT-29 and (B) HCA-7 cells, $48 \mathrm{~h}$ after InvColi strain infection. The invasion assay was performed using Boyden chambers and 8- $\mu$ m polycarbonate membranes coated with Matrigel (40-fold dilution). Samples were tested in the absence (dark bars) and in the presence (light bars) of PMA 40 nM. Relative invasion index refers to HT-29 and HCA-7 cells infected with InvColi-pS ${ }^{-}$, not treated with PMA. Data represent mean \pm s.e.m. of three independent experiments. *P $<0.0$ I.

expression, induces a significant impairment of malignant behaviour of HT-29 cells (Strillacci et al, 2006).

\section{CRC cell survival after bacterial infection depends on COX-2 overexpression}

It is known that COX-2 has a key role in colon cancer progression and survival of colon cancer cells. Recently, we demonstrated that a COX-2/CA-IX (carbonic anhydrase IX) interplay controls CRC cell survival under hypoxic conditions (Sansone et al, 2009). Therefore, we aimed to demonstrate that COX-2 overexpression is also required for the survival of CRC cells after infection of invasive E. coli strains. As we have previously demonstrated (Strillacci et al, 2006), COX-2 stable silencing mediated by retroviral transduction did not affect proliferation and survival of HT-29 cells. In fact, we did not record any difference in the proliferation rate between HT-29 ${ }^{\mathrm{pS}(-)}$ (negative control) and HT$29^{\mathrm{pS}(\mathrm{shCOX}-2)}$ (in which COX-2 is stably downregulated). However, after a prolonged infection with invasive InvColi-pS ${ }^{-}$(MOI 1:100, $6 \mathrm{~h}$ incubation, day 0 ), we observed a significant difference in cell proliferation and cell viability between $\mathrm{HT}-29^{\mathrm{pS}(-)}$ and HT$29^{\mathrm{pS}(\operatorname{shCOX}-2)}$ cells (Figure $7 \mathrm{~A}$ and B). At MOI 1:100, bacterial infection rapidly induced COX-2 overexpression in $\mathrm{HT}-29^{\mathrm{pS}(-)}$ cells (days $1-4$ ), most probably due to the higher presence of LPS (Hla and Neilson, 1992), but we did not observe this phenomenon in $\mathrm{HT}-29^{\mathrm{pS}(\mathrm{shCOX}-2)}$ cells (Figure $\left.7 \mathrm{C}\right)$. The lack of high COX-2 protein levels in infected HT-29 $9^{\text {PS(shCOX-2) }}$ cells led to a significant reduction in cell proliferation and viability. To further confirm the important role of the COX-2 protein in CRC cell survival, we performed InvColi-pS infection on HCT-116 cells, a CRC cell line not expressing the COX-2 protein. As expected, COX-2 protein and mRNA levels were not detectable in HCT-116 cells after $6 \mathrm{~h}$ infection with InvColi-pS strains at MOI 1:100 (data not shown). Importantly, the absence of COX-2 overexpression in infected HCT-116 cells led to a dramatic decrease in cell proliferation and viability (Figure 8A and B), as for HT-29 $9^{\mathrm{PS}(\operatorname{shCOX}-2)}$ cells. Moreover, infected HCT-116 cells showed a reduced ability to invade Matrigel-coated filters (Figure 8C).

\section{COX-2 silencing mediated by InvColi strains in colon tissue samples}

We evaluated the efficacy of COX-2 silencing ex vivo using InvColi-based RNAi on fresh colon tissue samples. To this purpose, samples were collected from patients affected by acute ulcerative colitis, supposed to be characterised by COX-2 protein expression. Levels of COX-2 protein, COX-2 mRNA and siCOX-2 were analysed $48 \mathrm{~h}$ after infection of biopsies with InvColi-pS strains (MOI 1:1000, $6 \mathrm{~h}$ incubation). As shown in Figure 9A, negative controls (untreated sample and sample infected with InvColi-pS ${ }^{-}$) were characterised by COX-2 expression, as expected. A significant COX-2 protein/mRNA reduction and siCOX-2 expression were recorded in samples infected with InvColi-pS ${ }^{\mathrm{H} 1}$, InvColi-pS ${ }^{\mathrm{COX} 2}$ and InvColi-pS ${ }^{\mathrm{TBE}}$, compared with negative controls. Very importantly, InvColi-pS ${ }^{\mathrm{TBE}}$ infection had the strongest effect, further confirming the in vitro data (see above). We also evaluated the effect of COX-2 silencing in colon tissues by analysing the levels of $\mathrm{PGE}_{2}$, cytokines, chemokines and growth factors present in the conditioned media $48 \mathrm{~h}$ after infection. For this analysis, only tissue samples infected with InvColi-pS ${ }^{-}$ (negative control) and InvColi-pS ${ }^{\mathrm{TBE}}$ (which showed the most effective COX-2 silencing) were taken into consideration and all data collected are shown in Figure 9B and C. As expected, COX-2 protein silencing mediated by $\operatorname{InvColi-pS^{\mathrm {TBE}}}$ led to a strong decrease in $\mathrm{PGE}_{2}$ secretion. Moreover, in media derived from InvColi- $\mathrm{pS}^{\mathrm{TBE}}$-infected cells, we found a significant decrease in IL-1 $\alpha$, IL-1 $\beta$, IL-6, IL-8, IL-12(p70), IL-17, PDGF-bb, bFGF, VEGF, IP-10, MCP-1 and MIP- $1 \beta$, whereas we observed a marked increase in IL-1ra, IL-2, IL-15, TNF $\alpha$ and Eotaxin. Levels of IL-4, IL-5 and IL-10 were not detectable. Interestingly, COX-2 silencing led to a strong decrease in the secretion of pro-inflammatory cytokines such as IL-1 $\alpha / \beta$ (Liu et al, 2003; Matsuo et al, 2009), IL-6 (Becker et al, 2005) or IL-8 (Brew et al, 2000), and that of pro-angiogenic growth factors such as PDGF-bb (Hsu et al, 1995), bFGF (Galzie et al, 1997) and VEGF (Takahashi et al, 1995). Furthermore, there was an increased secretion of some anti-inflammatory cytokines, such as IL-1ra (Konishi et al, 2005), and of cytokines with antitumour effect, such as IL-2 (Caporale et al, 2007) and IL-15 (Zhang et al, 2009). Similarly, TNF $\alpha$ increased secretion might exert an anti-tumour effect on colon cells, even if its role in CRC is still controversial (Koshiji et al, 1998; Popivanova et al, 2008). Thus, by a global analysis of ex vivo data, it results clear that InvColimediated RNAi induced COX-2 silencing and exerted an antiinflammatory and anti-tumour effect on colon cells.

\section{DISCUSSION}

Over the last decades, a large body of experimental evidence has ascribed to the COX-2 enzyme an important role in colorectal tumourigenesis. Cyclooxygenase- 2 is overexpressed in colon tumour tissues (Eberhart et al, 1994; Sano et al, 1995) and contributes to CRC progression and malignancy through mechanisms that act on cell proliferation/invasion (Yamauchi et al, 2002; Strillacci et al, 2006), apoptosis inhibition (Tsujii and DuBois, 

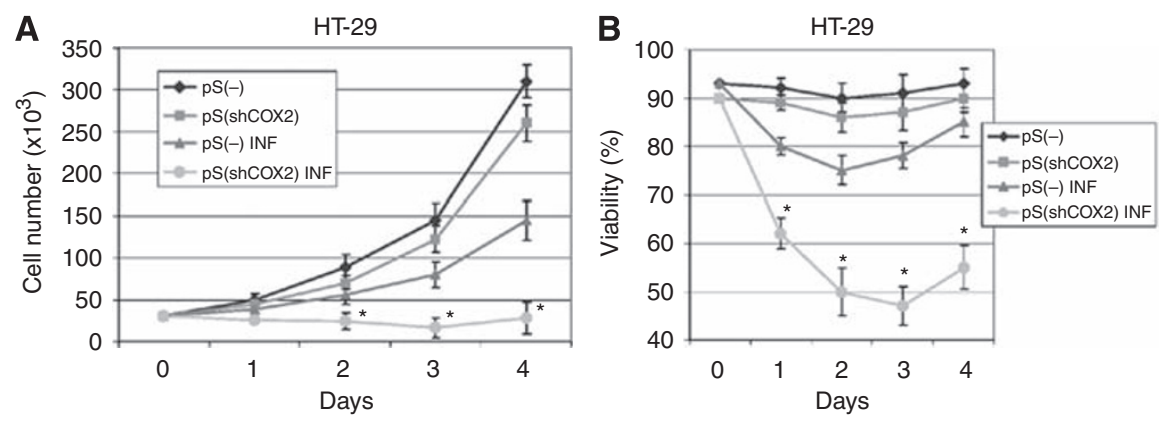

C

HT-29 InvColi-infected

Days

$\begin{array}{lllllllllllllll}0 & 1 & 2 & 3 & 4 & 0 & 1 & 2 & 3 & 4\end{array}$


Figure 7 HT-29 cell survival after bacterial infection depends on COX-2 overexpression. (A) Cell number, (B) cell viability and (C) COX-2 protein expression were evaluated in $\mathrm{HT}-29^{\mathrm{PS}(-)}$ and $\mathrm{HT}-29^{\mathrm{PS}(\text { shCOX-2) }}$ cells infected with InvColi-pS $(\mathrm{MOI}$ I:I 00), in comparison with control cells (not infected). See the 'Materials and Methods' section for details on cell lines. $(\bullet) \mathrm{HT}-29^{\mathrm{PS}(-)}$ cells, transduced with $\mathrm{pS}^{(-)}$' negative control vector; ( $\left.\mathbf{\square}\right) \mathrm{HT}-29^{\mathrm{PS}(\mathrm{shCOX}-2)}$ cells, transduced with $\mathrm{PS}^{(\text {shCOX-2) }}$ vector and stably silenced for COX-2 protein; $(\boldsymbol{\Delta})$ : HT-29PS(-) INF cells, transduced with $\mathrm{pS}^{(-)}$negative control vector

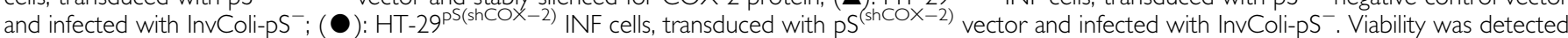
using the Trypan Blue exclusion assay and quantified as ((number of unstained cells)/(number of total cells)) $\times 100$. COX-2 protein expression was evaluated by western blot and normalised against $\beta$-actin protein. COX-2 relative expression refers to not infected HT-29PS(-) sample, day 0 . Data represent mean \pm s.e.m. of three independent experiments. $* P<0.01$.

1995) and tumour angiogenesis (Spisni and Tomasi, 1997; Iñiguez et al, 2003). It has been demonstrated that the chronic use of NSAIDs, inhibitors of COX activity, reduces CRC incidence in treated patients (Phillips et al, 2002; Thun et al, 2002; Higuchi et al, 2003; Sandler et al, 2003). Among these, 'coxibs' have been developed and marketed for the selective block of COX-2 activity. Celecoxib, rofecoxib, lumiracoxib and etoricoxib have been employed in many clinical trials to test their safety associated with the chronic use, but data collected are debated. The high incidence of cardiovascular adverse events is associated with the chronic use of coxibs (Bresalier et al, 2005; Solomon et al, 2005) and it seems clear that other pharmacological strategies, based on COX-2 inhibition, are required for the prevention and/or treatment of CRC.

Cyclooxygenase can be efficiently and selectively inhibited by RNAi techniques, either in a transient or a long-lasting manner (Strillacci et al, 2006). RNAi has become the first choice for gene silencing in vitro despite many disadvantages of RNAi approaches in vivo. RNAi-based silencing molecules can be delivered in vivo by intravenous injections or expressed by the use of viral-based systems. However, poor pharmacodynamics and/or heavy side effects reduce their use and effectiveness in vivo.

Hereby, we provide data supporting an alternative approach to target CRC cells and induce a highly selective COX-2 silencing, mediated by RNAi, both in vitro and ex vivo. In particular, we engineered invasive $E$. coli strains (InvColi) carrying siCOX-2 (siRNA sequences targeting COX-2 mRNA)-expressing vectors
(pSUPER.retro, pS). These bacteria were able to infect/invade CRC cells and release their DNA contents, leading to a strong COX-2 silencing.

First, we modified the pS vector to gain a tumour-specific shCOX-2 expression. The basic $\mathrm{pS}$ vector allows a constitutive expression of shCOX-2 (siCOX-2 precursor) in almost every human cell line as shCOX-2 transcription is driven by the $\mathrm{H} 1$ promoter for RNA pol III $\left(\mathrm{pS}^{\mathrm{H1}}\right)$. Thus, we modified this expression cassette by substituting the $\mathrm{H} 1$ promoter with the human Cox-2 promoter (in $\mathrm{pS}^{\mathrm{COX}-2}$ ) or with a promoter sequence containing TBEs (in $\mathrm{pS}^{\mathrm{TBE}}$ ), which represent the downstream target sequences on human genomic DNA of the $\mathrm{Wnt} / \beta$-cateninactivated pathway. It is well known that Cox-2 promoter activity is highly stimulated in CRC cells. Many cellular stimuli contribute to activate this phenomenon that leads to COX-2 overexpression (Yamamoto et al, 1995; Dixon et al, 2001; Duque et al, 2005; Wu et al, 2005; Kaidi et al, 2006; Strillacci et al, 2009). The Wnt $/ \beta$ catenin pathway is highly activated in CRC cells and such an activation is caused by cellular stimuli or by mutation of proteins involved in the pathway, such as APC or $\beta$-catenin itself (Morin et al, 1997; Brabletz et al, 2001, 2005; Castellone et al, $2005)$. By the use of $\mathrm{pS}^{\mathrm{COX}-2}$ and $\mathrm{pS}^{\mathrm{TBE}}$ vectors, we demonstrated that siCOX-2 can be expressed in a more effective and selective manner in CRC cells. Under Cox-2 or a TBE-based promoter control, siCOX-2 expression in CRC cell lines (HT-29 and HCA-7) was higher, if compared with H1-driven expression. On the 
A

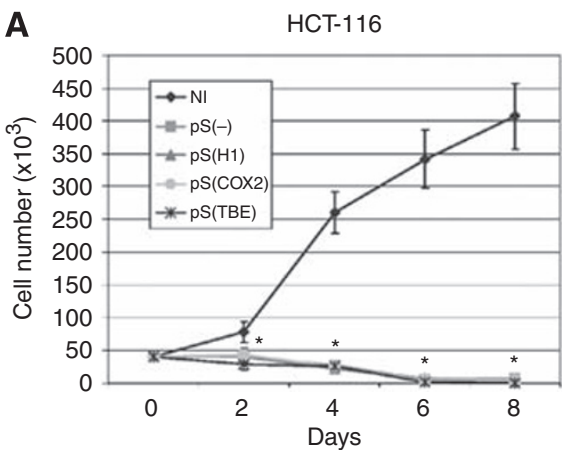

B

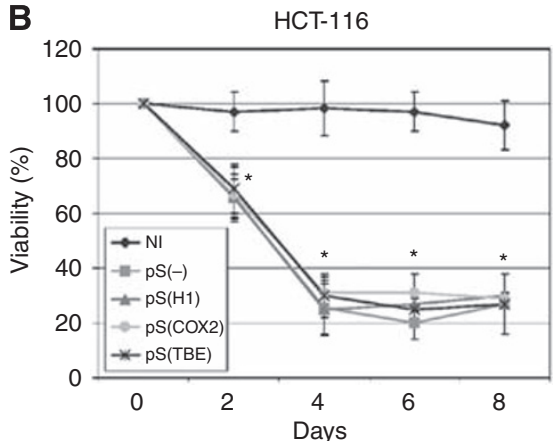

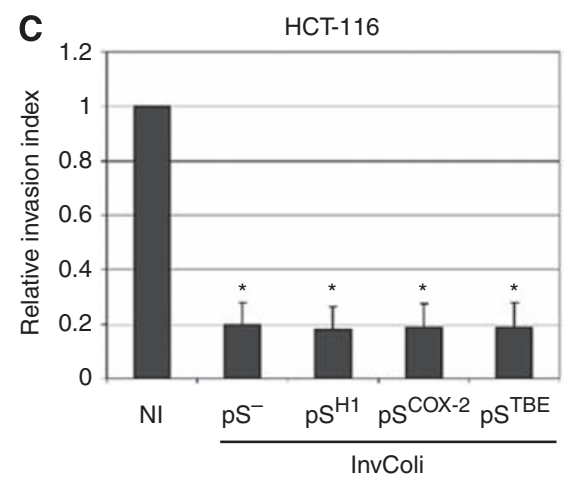

Figure 8 InvColi-pS infection impairs proliferation, viability and invasiveness of HCT-II6 cells. (A) Cell number, (B) cell viability and (C) invasiveness were evaluated in HCT-I I 6 cells infected by InvColi-pS strains (MOI I: I00). Viability was evaluated using the Trypan Blue exclusion assay and quantified as ((number of unstained cells)/(number of total cells)) × I00. ( $)$ : cells not infected, NI; ( $\mathbf{\square})$ : cells infected with InvColi-pS ${ }^{-}$; $(\boldsymbol{\Delta})$ : cells infected with InvColi$\mathrm{pS}^{\mathrm{HI}} ;(\mathbf{O})$ : cells infected with InvColi-pS ${ }^{\mathrm{COX}-2} ;\left({ }^{*}\right)$ : cells infected with InvColi-pS ${ }^{\mathrm{TBE}}$. The invasion assay was performed using Boyden chambers and 8- $\mu \mathrm{m}$ polycarbonate membranes coated with Matrigel (40-fold dilution). Relative invasion index refers to HCT-II6 cells not infected (NI). Data represent mean \pm s.e.m. of three independent experiments. $* P<0.01$.

contrary, siCOX-2 resulted in very low expression in normal colon epithelial cells (NCM-460) or in other human tumour cell lines (such as HeLa and HEK-293).

Second, we demonstrated that shCOX-2-expressing vectors $\left(\mathrm{pS}^{\mathrm{H} 1}, \mathrm{pS}^{\mathrm{COX}-2}\right.$ and $\left.\mathrm{pS}^{\mathrm{TBE}}\right)$ can be efficiently delivered into HT-29 and HCA-7 CRC cell lines after infection with InvColi strains (MOI 1:1000), thus promoting a strong COX-2 downregulation (both at mRNA and protein levels) mediated by RNAi and a prolonged reduction in $\mathrm{PGE}_{2}$ levels. Most likely, this phenomenon led to the significant reduction in cell proliferation, viability and invasiveness observed in infected CRC cells. Very interestingly, shCOX-2 expression driven by the TBE promoter induced the highest COX-2 silencing, which resulted in a strong impairment of the tumour-associated phenotype. It seems clear that, by using the $\mathrm{pS}^{\mathrm{TBE}}$ vector, it is possible to gain both efficacy and specificity for COX-2 silencing in CRC cells.

We used our model to further demonstrate the pivotal role of COX-2 overexpression in CRC cell survival. By infecting HT-29 cells stably silenced for COX-2 (HT-29 $9^{\mathrm{pS}(\text { shCox }-2)}$, previously developed in our laboratory) with InvColi-pS ${ }^{-}$at a higher MOI value (1:100), we observed a significant reduction in cell proliferation and survival, with respect to the negative control $\left(\mathrm{HT}-29^{\mathrm{pS}(-)}\right.$ cells). As it is well known that bacterial LPS induces COX-2 expression in human cells and, as we show herein, InvColi$\mathrm{pS}^{-}$infection at an MOI 1:100 induces COX-2 overexpression in CRC cells, our hypothesis is that the survival of CRC cells after bacterial infection could be strictly dependent on COX-2 induction. This observation was further confirmed in HCT-116 cells, a CRC cell line unable to express COX-2. In fact, the lack of COX-2 protein induction after InvColi-pS strain infection led to a significant impairment of cell proliferation, viability and invasiveness of HCT-116 cells. We did not record differences between the four InvColi-pS strains used for HCT-116 infection. InvColi-pS ${ }^{-}$ infection had the same effect of InvColi-pS ${ }^{\mathrm{H} 1}$, InvColi-pS ${ }^{\mathrm{COX} 2}$ and InvColi-pS ${ }^{\mathrm{TBE}}$ infection. Thus, as for HT-29 $9^{\mathrm{pS}(\operatorname{shCOX}-2)}$, the biological effect on HCT-116 cells was dependent on InvColi-pS infection per se, rather than on siCOX-2 expression. On the other hand, the global effect of InvColi-pS infection on CRC cell lines expressing COX-2 (HCA-7 and HT-29) is the result of COX-2 silencing mediated by $\mathrm{RNAi}, \mathrm{PGE}_{2}$ levels reduction and cellular stress induced by bacteria infection.

Finally, in the light of a possible in vivo application, we tested ex vivo the efficacy of selective COX-2 silencing mediated by InvColibased RNAi. Colon tissue samples, derived from patients affected by acute ulcerative colitis and expressing COX-2 protein, were infected with InvColi-pS strains and this resulted in a strong COX-2 inhibition at both mRNA and protein levels, especially after infection with InvColi-pS ${ }^{\mathrm{TBE}}$. Cyclooxygenase-2 silencing was associated with a significant reduction in $\mathrm{PGE}_{2}$ and pro-inflammatory/ pro-angiogenic factors (cytokines, growth factors) released by colon InvColi-pS ${ }^{\mathrm{TBE}}$-infected cells. Moreover, we observed an increased production of factors with anti-inflammatory and anti-tumour effects.

In conclusion, we developed an RNAi-based strategy to efficiently and specifically silence the COX-2 protein in CRC cells, in vitro and ex vivo. Cyclooxygenase-2 downregulation, depending on InvColi-pS infection, induced a strong impairment of both proliferative and invasive behaviour of CRC cells in vitro and a significant anti-inflammatory and anti-tumour effect ex vivo. Taken together, our data demonstrate the feasibility of an RNAibased/InvColi-driven approach for COX-2 silencing aimed at the prevention of CRC or the treatment of other inflammatory bowel diseases characterised by COX-2 overexpression. Using engineered E. coli strains or other non-pathogenic bacteria, siCOX-2 silencing could be locally delivered and expressed in colorectal tissues, thus promoting a blockade of COX-2 activity, supposedly deprived of systemic side effects. 
RNAi and COX-2 silencing in CRC cells

A Strillacci et al

A



B

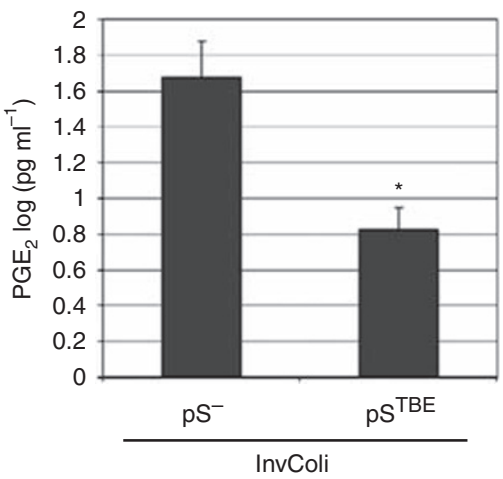

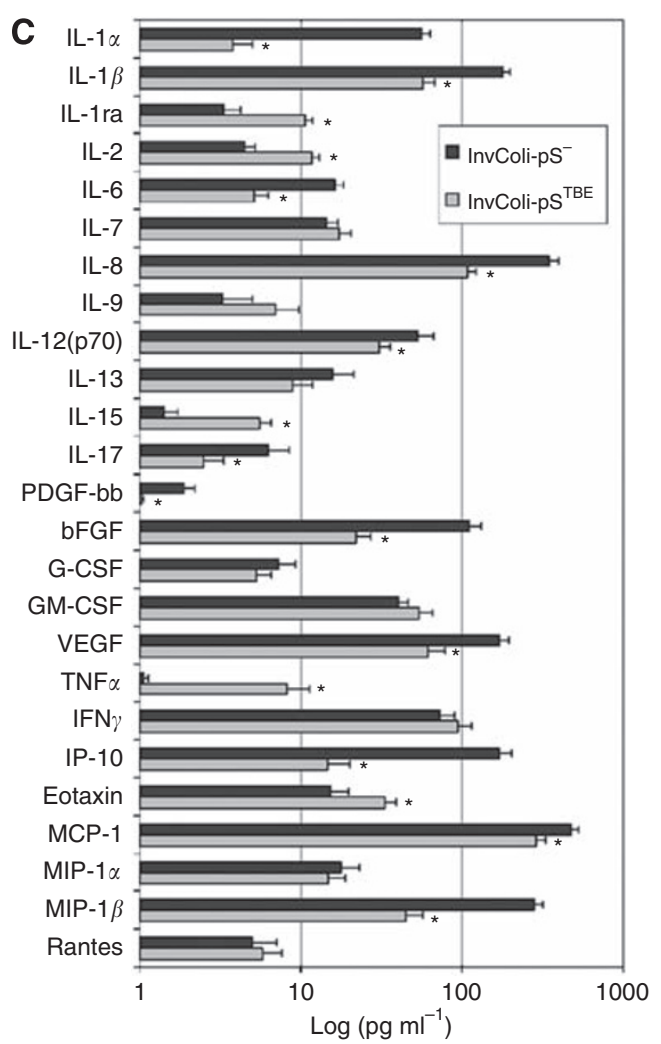

Figure 9 InvColi-pS strains infect colon tissue samples and induce high COX-2 silencing associated with anti-inflammatory and anti-angiogenic effects. (A) COX-2 protein, COX-2 mRNA and siCOX-2 levels were analysed in colon tissue samples by western blot and real-time PCR, $48 \mathrm{~h}$ after InvColi strain infection. COX-2 protein, COX-2 mRNA and siCOX-2 expression was normalised against $\beta$-actin protein, GUSB ( $\beta$-glucuronidase) mRNA and U6 RNA levels, respectively. Relative expression of COX-2 protein and COX-2 mRNA refers to not infected samples (negative control, NC); relative expression of siCOX-2 refers to InvColi-pS TBE infected samples. Data represent mean \pm s.e.m. of three independent experiments. $* P<0.01$. (B) Levels of PGE 2 , (C) cytokines, chemokines and growth factors were quantified in InvColi-pS ${ }^{-}$- and InvColi-pS ${ }^{T_{B E}}$-infected colon tissues conditioned media, $48 \mathrm{~h}$ after infection, by a Luminex-based multiplexed bead immunoassay. Concentration values are expressed as $\log \left(\mathrm{pg} \mathrm{ml}^{-1}\right)$ and represent mean $\pm \mathrm{CV}$ of three independent measurements, normalised considering the total protein amount extracted from each tissue sample. $* P<0.0$ l.

\section{ACKNOWLEDGEMENTS}

This work was supported by grants from MIUR (FIRB 2003 RBNE03FMCJ to VT and PRIN 2008MT34AP to ES). We also thank Dr Catherine Grillot-Courvalin (Unité des Agents Antibactériens, Institut Pasteur, Paris) for providing us pGB2- $\Omega$-inv-hly plasmid and Dr Hans Clevers (University Hospital, Utrecht, The Netherlands) for providing us TOPFLASH plasmid.

Supplementary Information accompanies the paper on British Journal of Cancer website (http://www.nature.com/bjc) 


\section{REFERENCES}

Becker C, Fantini MC, Wirtz S, Nikolaev A, Lehr HA, Galle PR, Rose-John S, Neurath MF (2005) IL-6 signaling promotes tumor growth in colorectal cancer. Cell Cycle 4: 217-220

Brabletz T, Hlubek F, Spaderna S, Schmalhofer O, Hiendlmeyer E, Jung A, Kirchner $\mathrm{T}$ (2005) Invasion and metastasis in colorectal cancer: epithelial-mesenchymal transition, mesenchymal-epithelial transition, stem cells and beta-catenin. Cells Tissues Organs 179: 56-65

Brabletz T, Jung A, Reu S, Porzner M, Hlubek F, Kunz-Schughart LA, Knuechel R, Kirchner T (2001) Variable beta-catenin expression in colorectal cancers indicates tumor progression driven by the tumor environment. Proc Natl Acad Sci USA 98: 10356-10361

Bresalier RS, Sandler RS, Quan H, Bolognese JA, Oxenius B, Horgan K, Lines C, Riddell R, Morton D, Lanas A, Konstam MA, Baron JA, Adenomatous Polyp Prevention on Vioxx (APPROVe) Trial Investigators (2005) Cardiovascular events associated with rofecoxib in a colorectal adenoma chemoprevention trial. $N$ Engl J Med 352: $1092-1102$

Brew R, Erikson JS, West DC, Kinsella AR, Slavin J, Christmas SE (2000) Interleukin-8 as an autocrine growth factor for human colon carcinoma cells in vitro. Cytokine 12: $78-85$

Brummelkamp TR, Bernards R, Agami R (2002) Stable suppression of tumorigenicity by virus-mediated RNA interference. Cancer Cell 2: 243-247

Caporale A, Brescia A, Galati G, Castelli M, Saputo S, Terrenato I, Cucina A, Liverani A, Gasparrini M, Ciardi A, Scarpini M, Cosenza UM (2007) Locoregional IL-2 therapy in the treatment of colon cancer. Cell-induced lesions of a murine model. Anticancer Res 27: 985-989

Castagliuolo I, Beggiao E, Brun P, Barzon L, Goussard S, Manganelli R, Grillot-Courvalin C, Palù G (2005) Engineered E. coli delivers therapeutic genes to the colonic mucosa. Gene Ther 12: 1070-1078

Castellone MD, Teramoto H, Williams BO, Druey KM, Gutkind JS (2005) Prostaglandin E2 promotes colon cancer cell growth through a Gs-axinbeta-catenin signaling axis. Science 310: $1504-1510$

Chen C, Ridzon DA, Broomer AJ, Zhou Z, Lee DH, Nguyen JT, Barbisin M, $\mathrm{Xu}$ NL, Mahuvakar VR, Andersen MR, Lao KQ, Livak KJ, Guegler KJ (2005) Real-time quantification of microRNAs by stem-loop RT-PCR. Nucleic Acids Res 33: e179

Crofford LJ, Wilder RL, Ristimäki AP, Sano H, Remmers EF, Epps HR, Hla T (1994) Cyclooxygenase- 1 and -2 expression in rheumatoid synovial tissues. Effects of interleukin-1 beta, phorbol ester, and corticosteroids. J Clin Invest 93: 1095-1101

Dixon DA, Tolley ND, King PH, Nabors LB, McIntyre TM, Zimmerman GA, Prescott SM (2001) Altered expression of the mRNA stability factor HuR promotes cyclooxygenase-2 expression in colon cancer cells. J Clin Invest 108: $1657-1665$

DuBois RN, Radhika A, Reddy BS, Entingh AJ (1996) Increased cyclooxygenase-2 levels in carcinogen-induced rat colonic tumors. Gastroenterology 110: 1259-1262

Duque J, Fresno M, Iñiguez MA (2005) Expression and function of the nuclear factor of activated $\mathrm{T}$ cells in colon carcinoma cells: involvement in the regulation of cyclooxygenase-2. J Biol Chem 280: 8686-8693

Eberhart CE, Coffey RJ, Radhika A, Giardiello FM, Ferrenbach S, DuBois RN (1994) Up-regulation of cyclooxygenase 2 gene expression in human colorectal adenomas and adenocarcinomas. Gastroenterology 107: $1183-1188$

Ferlay J, Autier P, Boniol M, Heanue M, Colombet M, Boyle P (2007) Estimates of the cancer incidence and mortality in Europe in 2006. Ann Oncol 18: $581-592$

Galzie Z, Fernig DG, Smith JA, Poston GJ, Kinsella AR (1997) Invasion of human colorectal carcinoma cells is promoted by endogenous basic fibroblast growth factor. Int J Cancer 71: 390-395

Griffoni C, Spisni E, Strillacci A, Toni M, Bachschmid MM, Tomasi V (2007) Selective inhibition of prostacyclin synthase activity by rofecoxib. J Cell Mol Med 11: 327-338

Grillot-Courvalin C, Goussard S, Huetz F, Ojcius DM, Courvalin P (1998) Functional gene transfer from intracellular bacteria to mammalian cells. Nat Biotechnol 16: $862-866$

Han SY, Lee MS, Kim HR, Baek SH, Ahn DH, Chae HS, Erickson RH, Sleisenger MH, Kim YS (2000) Phorbol 12-myristate 13-acetate induces alteration in mucin gene expression and biological properties of colon cancer cells. Int J Oncol 17: 487-494

Higuchi T, Iwama T, Yoshinaga K, Toyooka M, Taketo MM, Sugihara K (2003) A randomized, double-blind, placebo-controlled trial of the effects of rofecoxib, a selective cyclooxygenase-2 inhibitor, on rectal polyps in familial adenomatous polyposis patients. Clin Cancer Res 9: 4756-4760
Hla T, Neilson K (1992) Human cyclooxygenase-2 cDNA. Proc Natl Acad Sci USA 89: $7384-7388$

Hsu S, Huang F, Friedman E (1995) Platelet-derived growth factor-B increases colon cancer cell growth in vivo by a paracrine effect. J Cell Physiol 165: 239-245

Iñiguez MA, Rodriguez A, Volpert OV, Fresno M, Redondo JM (2003) Cyclooxygenase-2: a therapeutic target in angiogenesis. Trends Mol Med 9: $73-78$

Kaidi A, Qualtrough D, Williams AC, Paraskeva C (2006) Direct transcriptional up-regulation of cyclooxygenase-2 by hypoxia-inducible factor (HIF)-1 promotes colorectal tumor cell survival and enhances HIF-1 transcriptional activity during hypoxia. Cancer Res 66: 6683-6691

Konishi N, Miki C, Yoshida T, Tanaka K, Toiyama Y, Kusunoki M (2005) Interleukin-1 receptor antagonist inhibits the expression of vascular endothelial growth factor in colorectal carcinoma. Oncology 68: 138-145

Koshiji M, Adachi Y, Sogo S, Taketani S, Oyaizu N, Than S, Inaba M, Phawa S, Hioki K, Ikehara S (1998) Apoptosis of colorectal adenocarcinoma (COLO 201) by tumour necrosis factor-alpha (TNF-alpha) and/or interferon-gamma (IFN-gamma), resulting from down-modulation of Bcl-2 expression. Clin Exp Immunol 111: 211-218

Lewis DL, Hagstrom JE, Loomis AG, Wolff JA, Herweijer H (2002) Efficient delivery of siRNA for inhibition of gene expression in postnatal mice. Nat Genet 32: 107-108

Liu W, Reinmuth N, Stoeltzing O, Parikh AA, Tellez C, Williams S, Jung YD, Fan F, Takeda A, Akagi M, Bar-Eli M, Gallick GE, Ellis LM (2003) Cyclooxygenase- 2 is up-regulated by interleukin-1 beta in human colorectal cancer cells via multiple signaling pathways. Cancer Res 63: 3632-3636

Matsuo Y, Sawai H, Ma J, Xu D, Ochi N, Yasuda A, Takahashi H, Funahashi H, Takeyama H (2009) IL-1alpha secreted by colon cancer cells enhances angiogenesis: the relationship between IL-1alpha release and tumor cells' potential for liver metastasis. J Surg Oncol 99: 361-367

Morin PJ, Sparks AB, Korinek V, Barker N, Clevers H, Vogelstein B, Kinzler KW (1997) Activation of beta-catenin-Tcf signaling in colon cancer by mutations in beta-catenin or APC. Science 275: 1787-1790

Moyer MP, Manzano LA, Merriman RL, Stauffer JS, Tanzer LR (1996) NCM460, anormal human colon mucosal epithelial cell line. In Vitro Cell Dev Biol Anim 32: 315-317

Oshima M, Dinchuk JE, Kargman SL, Oshima H, Hancock B, Kwong E, Trzaskos JM, Evans JF, Taketo MM (1996) Suppression of intestinal polyposis in Apc delta716 knockout mice by inhibition of cyclooxygenase 2 (COX-2). Cell 87: 803-809

Phillips RK, Wallace MH, Lynch PM, Hawk E, Gordon GB, Saunders BP, Wakabayashi N, Shen Y, Zimmerman S, Godio L, Rodrigues-Bigas M, Su LK, Sherman J, Kelloff G, Levin B, Steinbach G, FAP Study Group (2002) A randomized, double blind, placebo controlled study of celecoxib, a selective cyclooxygenase 2 inhibitor, on duodenal polyposis in familial adenomatous polyposis. Gut 50: $857-860$

Popivanova BK, Kitamura K, Wu Y, Kondo T, Kagaya T, Kaneko S, Oshima M, Fujii C, Mukaida N (2008) Blocking TNF-alpha in mice reduces colorectal carcinogenesis associated with chronic colitis. J Clin Invest 118: $560-570$

Sandler RS, Halabi S, Baron JA, Budinger S, Paskett E, Keresztes R, Petrelli N, Pipas JM, Karp DD, Loprinzi CL, Steinbach G, Schilsky R (2003) A randomized trial of aspirin to prevent colorectal adenomas in patients with previous colorectal cancer. $N$ Engl J Med 348: 883-890

Sano H, Kawahito Y, Wilder RL, Hashiramoto A, Mukai S, Asai K, Kimura S, Kato H, Kondo M, Hla T (1995) Expression of cyclooxygenase-1 and -2 in human colorectal cancer. Cancer Res 55: 3785-3789

Sansone P, Piazzi G, Paterini P, Strillacci A, Ceccarelli C, Minni F, Biasco G, Chieco P, Bonafè M (2009) Cyclooxygenase-2/Carbonic anhydrase-IX upregulation promotes invasive potential and hypoxia survival in colorectal cancer cells. J Cell Mol Med 13: 3876-3887

Sledz CA, Holko M, de Veer MJ, Silverman RH, Williams BRG (2003) Activation of the interferon system by short-interfering RNAs. Nature Cell Biol 5: 834-839

Solomon SD, McMurray JJ, Pfeffer MA, Wittes J, Fowler R, Finn P, Anderson WF, Zauber A, Hawk E, Bertagnolli M, Adenoma Prevention with Celecoxib (APC) Study Investigators (2005) Cardiovascular risk associated with celecoxib in a clinical trial for colorectal adenoma prevention. N Engl J Med 352: $1071-1080$

Spisni E, Tomasi V (1997) Involvement of prostanoid in angiogenesis. In Tumour Angiogenesis. Bicknell R, Lewis CE, Ferrara N (Eds). Oxford University Press: Oxford, UK. pp 291-300 
RNAi and COX-2 silencing in CRC cells

A Strillacci et al

Strillacci A, Griffoni C, Sansone P, Paterini P, Piazzi G, Lazzarini G, Spisni E, Pantaleo MA, Biasco G, Tomasi V (2009) MiR-101 is involved in cyclooxygenase-2 overexpression in human colon cancer cells. Exp Cell Res 315: 1439-1447

Strillacci A, Griffoni C, Spisni E, Manara MC, Tomasi V (2006) RNA interference as a key to knockdown overexpressed cyclooxygenase-2 gene in tumor cells. Br J Cancer 94: 1300-1310

Strillacci A, Griffoni C, Valerii MC, Lazzarini G, Tomasi V, Spisni E (2010) RNAi-based strategies for cyclooxygenase-2 (COX-2) inhibition in cancer. RNAi-based strategies for cyclooxygenase-2 (COX-2) inhibition in cancer. J Biomed Biotechnol 2010: 828045

Takahashi Y, Kitadai Y, Bucana CD, Cleary KR, Ellis LM (1995) Expression of vascular endothelial growth factor and its receptor, KDR, correlates with vascularity, metastasis, and proliferation of human colon cancer. Cancer Res 55: $3964-3968$

Thun MJ, Henley SJ, Patrono C (2002) Nonsteroidal anti-inflammatory drugs as anticancer agents: mechanistic, pharmacologic, and clinical issues. J Natl Cancer Inst 94: 252-266

Tsujii M, DuBois RN (1995) Alterations in cellular adhesion and apoptosis in epithelial cells overexpressing prostaglandin endoperoxide synthase 2 . Cell 83: 493-501
Williams CS, Luongo C, Radhika A, Zhang T, Lamps LW, Nanney LB, Beauchamp RD, DuBois RN (1996) Elevated cyclooxygenase-2 levels in Min mouse adenomas. Gastroenterology 111: 1134-1140

Wu KK, Liou JY, Cieslik K (2005) Transcriptional control of COX-2 via C/ EBPbeta. Arterioscler Thromb Vasc Biol 25: 679-685

Xiang S, Fruehauf J, Li CJ (2006) Short hairpin RNA-expressing bacteria elicit RNA interference in mammals. Nat Biotechnol 24: $697-702$

Yamamoto K, Arakawa T, Ueda N, Yamamoto S (1995) Transcriptional roles of nuclear factor kappa $B$ and nuclear factorinterleukin-6 in the tumor necrosis factor alpha-dependent induction of cyclooxygenase-2 in MC3T3-E1 cells. $J$ Biol Chem 270: $31315-31320$

Yamauchi T, Watanabe M, Kubota T, Hasegawa H, Ishii Y, Endo T, Kabeshima Y, Yorozuya K, Yamamoto K, Mukai M, Kitajima M (2002) Cyclooxygenase-2 expression as a new marker for patients with colorectal cancer. Dis Colon Rectum 45: $98-103$

Zhang M, Yao Z, Dubois S, Ju W, Müller JR, Waldmann TA (2009) Interleukin-15 combined with an anti-CD40 antibody provides enhanced therapeutic efficacy for murine models of colon cancer. Proc Natl Acad Sci USA 106: $7513-7518$ 